\title{
A Preliminary Assessment of Archaeological Resources at Tobins Oakwell Farm, San Antonio, Texas
}

\author{
A. Joachim McGraw \\ Fred Valdez Jr. \\ Department of Anthropology, The University of Texas at Austin
}

Follow this and additional works at: https://scholarworks.sfasu.edu/ita

Part of the American Material Culture Commons, Archaeological Anthropology Commons, Environmental Studies Commons, Other American Studies Commons, Other Arts and Humanities Commons, Other History of Art, Architecture, and Archaeology Commons, and the United States History Commons

Tell us how this article helped you.

This Article is brought to you for free and open access by the Center for Regional Heritage Research at SFA ScholarWorks. It has been accepted for inclusion in Index of Texas Archaeology: Open Access Gray Literature from the Lone Star State by an authorized editor of SFA ScholarWorks. For more information, please contact cdsscholarworks@sfasu.edu. 
A Preliminary Assessment of Archaeological Resources at Tobins Oakwell Farm, San Antonio, Texas

\section{Creative Commons License}

\section{(c) (1) (8)}

This work is licensed under a Creative Commons Attribution-NonCommercial 4.0 International License 


\section{Prelliminary Hssessment of

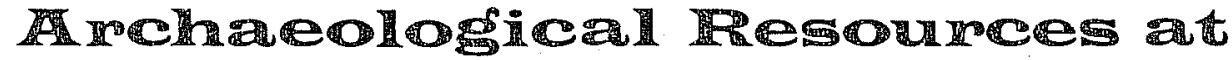 11

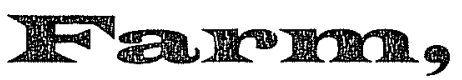 San intomio, Texas}

A. JOACHIM McGRAW AND FRED VALDEZ, JR.

CENTER FOR ARCHAEOLOGICAL RESEARCH

THE UNIVERSITY OF TEXAS AT SAN ANTONIO

ARCHAEOLOGICAL SURVEY REPORT, NO. 43

1977 
A PRELIMINARY ASSESSMENT OF ARCHAEOLOGICAL RESOURCES AT

TOBINS OAKWELL FARM, SAN ANTONIO, TEXAS

A. Joachim McGraw and Fred Valdez, Jr.

Center for Archaeological Research

The University of Texas at San Antonio

Archaeological Survey Report, No. 43

1977 
Introduction ................ 1

The Survey . . . . . . . . . . . . . 1

Previous Archaeological Research . . . . . . . . 3

Physical Environment ............ 3

Chronology of Prehistoric Habitation ........ 5

Site Descriptions .............. 6

The Artifacts ............... . . 14

Summary and Recommendations .......... 14

References Cited............. 18

\section{LIST OF FIGURES}

Figures

Page

1. Map of Tobins Oakwell Farm Project Area

Showing Locations of Archaeological Sites . . . . 2

2. Tobins Oakwell Farm: Site Locations ....... 9

3. Tobins 0akwell Farm: Site Locations . . . . . . 11

4. Tobins Oakwell Farm: Site Locations . . . . . . 12

5. Tobins Oakwell Farm: Site Location . . . . . 13

6. Lithic Artifacts ............ 15

7. Lithic Artifacts ........... 16 


\section{INTRODUCTION}

A preliminary archaeological survey and assessment of the Tobins 0akwell Farm project area was conducted during August 22-24, 1977, by archaeologists from the Center for Archaeological Research, The University of Texas at San Antonio (UTSA). The work was conducted with in two nearby but separate areas adjacent to Salado Creek within the city limits of San Antonio, northern Bexar County. The investigation was performed under a contract between the Center and Ford, Powell and Carson, architects and planners.

The intent of the survey was to locate any unrecorded archaeological sites in the study area before their destruction or alteration by planned developments. To determine the significance of the project area, the survey team from the Center followed the guidelines listed below:

1) determine if archaeological resources exist within the areas of land committed to the project,

2) identify, record and appraise the significance of any sites found, and

3) provide recommendations for further research if adverse impacts are anticipated.

The field work was conducted under the direction of Dr. Thomas R. Hester, Director, Center for Archaeological Research, and Mr. Jack Eaton, Assistant Director.

\section{THE SURVEY}

The field survey investigated both the lower stream drainages of Salado Creek as well as slopes and adjacent upland areas. Although temporal limitations and heavy vegetation forced the survey team to give primary survey considerations to locations which suggested the greatest potential for prehistoric activity, all areas within the planning boundaries were traversed (Fig. 1).

The investigation of the 0akwell Farm project area was based upon a systematic investigation which generally followed the guidelines presented in Field Methods in Archaeology (Hester, Heizer and Graham 1975). The methodology emphasized such elements as: 1) the use of as much accuracy as possible in describing, analyzing and evaluating identified sites; 2) attempts to set forth reasonable guidelines to aid further studies; and 3) the formulation of conclusions relevant to the study of cultural processes. Material distributions, such as lithic concentrations, were of special importance not only to define site boundaries but also to identify areas of specific activity. Consideration was also given to the presence or absence of particular cultural materials as well as their distance and elevation from sources of water. Controlled surface collection was rejected as too inefficient in both time and manpower requirements, and emphasis was directed at obtaining as complete a sample as possible of diagnostic artifacts from all areas of the project. 


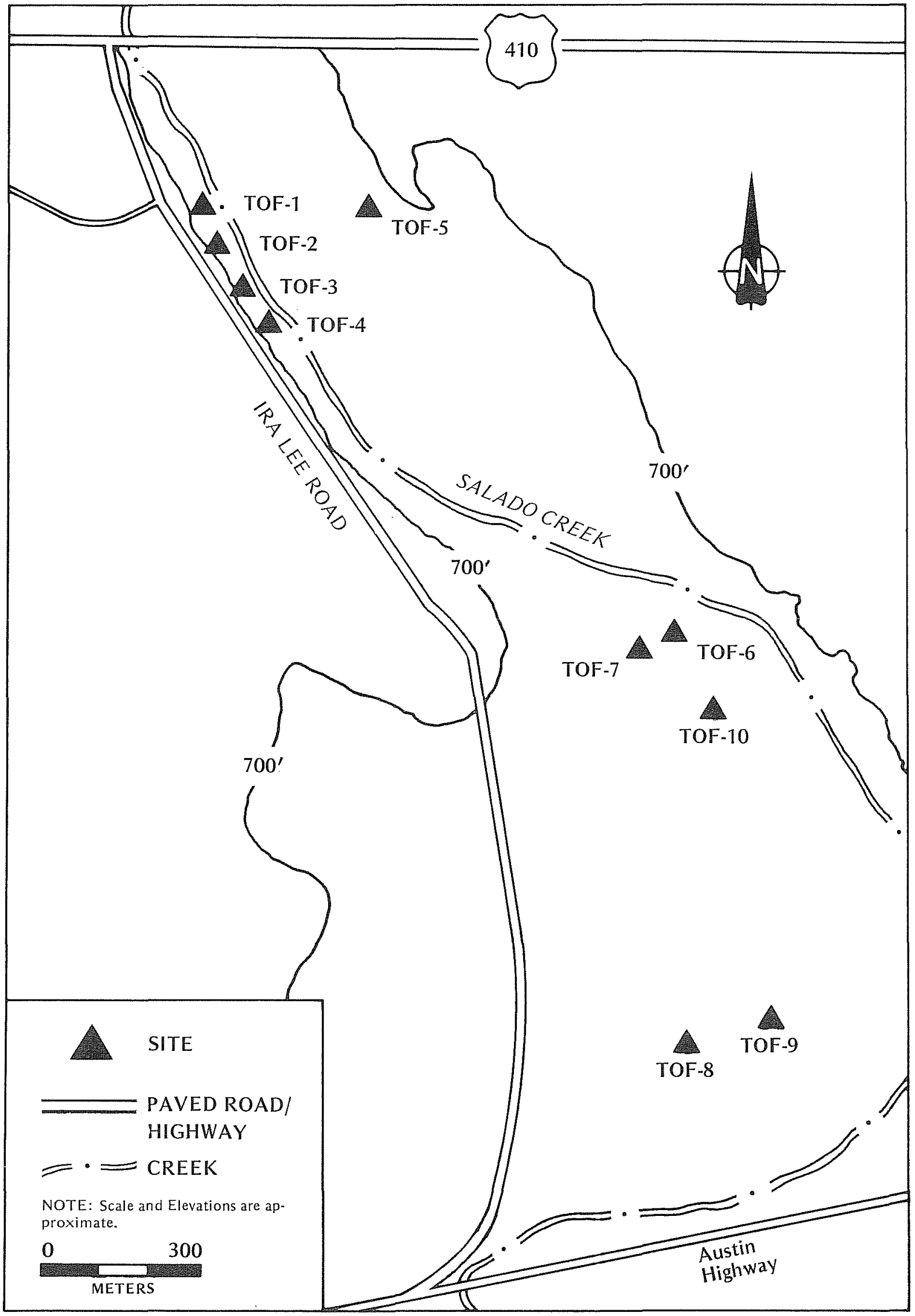

Figure 1. Map of Tobins Oakwell Farm Project Area Showing Locations of Archaeological sites. 
A11 sites identified in the 0akwell Farm project area have been recorded on standard site survey forms presently in use by the Center. Photographic documentation was accomplished by $35 \mathrm{~mm}$ black-and-white photographs, color slides and Polaroid record photographs. A11 sites have been plotted on United States Geological Survey topographic maps. Artifacts were collected at most sites and placed in plastic or paper bags and labeled as to surveyed area, site number, date, type of collection and collector's name. All materials collected were processed according to standard archaeological procedures. The assessments presented in this preliminary report are based upon careful analysis of artifacts, photographs, survey forms and comprehensive field notes.

\section{PREVIOUS ARCHAEOLOGICAL RESEARCH}

The Tobins 0akwe11 Farm project area is located in one of the most archaeologically studied counties of Texas. Over 470 aboriginal or historic sites have been recorded in Bexar County to date, but unfortunately, most research in the area has been in the form of surveys and only limited subsurface investigations have taken place. A summary of earlier work has been published by Fawcett (1972; see also Woolford 1935 and Hester 1975). Fawcett's work contains a bibliography of published and unpublished reports dealing with Bexar County archaeological research. Investigations in northern Bexar County (in the vicinity of the 0akwell Farm project area within the past three years) include archaeological surveys of the Salado Creek watershed (Hester et al. 1974), an archaeological survey of Friedrich Park (Smith and McDonald 1975), a brief description of the Menger Collection (Chadderdon 1975), an archaeological survey in the Encino Park Development (McGraw, Valdez and Cox 1977), fuil scale excavations by T. R. Hester at 41 BX 229 (the St. Mary's Hall Site), and limited excavations and testing at 41 BX 228 (Walker Ranch) in summer 1977.

The orientation of former work has been directed toward site specificity and an actual synthesis of existing reports is lacking. However, Fawcett (1974) and Gerstle, Kelly and Assad (1977) have addressed this problem. Many of the archaeological sites reported in the county are from areas on or near the Salado Creek drainage, which suggests intensive aboriginal activity during the prehistoric period. Some of the more important sites in the vicinity of the project area include the St. Mary's Hall Site (41 BX 229), the Granberg Site (Schuetz 1966), the Granberg II Site (Hester and Kohnitz 1975) and a series of sites on the Walker Ranch reported by Scurlock and Hudson (1973), Hudson, Lynn and Scurlock (1974) and Hester et al. (1974).

\section{PHYSICAL ENVIRONMENT}

The 0akwell Farm project area is located on the edge of the Balcones Fault Zone and also lies on the edge of a broad transition area that separates the lowerlying county of the Gulf Coastal Plain from the Edwards Plateau Escarpment. Local topography along the Salado Creek drainage is generally composed of a 
shallow but wide stream channel (often as wide as 5-6 m) adjacent to steep slopes; upland areas are commonly 8-10 m above the floodplain. Geology within the low-lying areas of the drainage consists of alluvial redepositions while the slopes are heavily eroded with prominent limestone outcroppings. The limestone formations in the project area are part of the lower cretaceous Formations of the Mesozoic Era. Often hundreds of feet thick, they are composed of fine to coarse-grained materials and abundant chert and are colored medium grey to greyish-brown. Surface elevations in the locality vary from ca. $706^{\prime}$ in the northern upland margins to $670^{\prime}$ above mean sea level (msl) in other areas.

\section{Soils}

Soils throughout this area generally fall into the Venus-Frio-Trinity Association with deep calcareous soils on bottom lands and terraces. This association is bordered by Austin-Tarrant and Houston Black-Houston soils. Specific soil types in the study areas include Trinity and Frio soils; frequently flooded, Patrick-type soils along the slopes; and disturbed soils in large pits and quarries (Taylor et al. 1966).

\section{climate}

Climate throughout the Bexar County area is generally sub-tropical with comparatively hot summers and mild winters. The average daily maximum and minimum temperatures, respectively, are $79.2^{\circ}$ and $58.1^{\circ} \mathrm{F}$. Precipitation averages 27.89 inches and occurs throughout the year in the form of thunderstorms, which often cause serious flooding of low-water areas and local waterways. Relative humidity normally ranges from $80 \%$ in the morning hours to $50 \%$ by 1 ate afternoon. Northerly winds predominate during the winter and southeasterly Gulf winds prevail during the summer. The period from the last spring freeze to the first in the fall averages 245 days (Taylor et al. 1966).

\section{Flora and Fauna}

In the past, a wide variety of flora has occupied the assortments of microenvironments created by the drainage patterns and upland areas. Wild grasses have included little and feathery bluestem, gramas, side-oats, green sprangletop, Texas cup-grass, Plains lore-grass, Indian grass, buffalo grass and others. Climax vegetation presently includes Texas persimmon (Diospyros texenis), mesquite (Prosopis juliflora), scrub live oak (Quercus spp.), pecan, several species of cacti, and a wide variety of scrub brush (see also Blair 1950).

The fauna are typical of Blair's (1950:102 ff) Tamaulipan Biotic Province. However, Bexar County borders on the Balconian Biotic Province and shares some of the fauna found in that area.

Those readers interested in a more detailed account of the geology, soils, vegetation and faunal patterns in the area are referred to Blair (1950), Fawcett (1972), Scurlock and Hudson (1973), Taylor et al. (1966), Carr (1969) and McGraw, Valdez and Cox (1977). 


\section{CHRONOLOGY OF PREHISTORIC HABITATION}

Earlier research in northern Bexar County has identified distinct types of prehistoric sites: occupations (campsites), burned rock middens, chert quarries, lithic workshops, temporary campsites and rockshelters. (For additional descriptions of Bexar County sites see Fawcett 1972 and Gerstle, Kelly and Assad 1977.) The dating of such sites is, at best, no more than approximate. Four major time periods are represented in the vicinity of the Oakwell Farm project area. These are defined as the Paleo-Indian, the Archaic, the Late Prehistoric (Neo-American) and the Historic periods.

The Paleo-Indian period (ca. 9200-6000 B.C.) is represented less than $2 \mathrm{~km}$ north of the study area at 41 BX 229, the St. Mary's Hall Site. Folsom and Plainview projectile points have been discovered at this locality and current analysis suggests this was a relatively extensive occupation area. A large chert quarry in excess of $30,000 \mathrm{~m}^{2}$ and about $1.5 \mathrm{~km}$ south of $41 \mathrm{BX} 229$ may reflect specific aboriginal interests and activity patterns southward in the direction of the present 0akwell Farms project area.

Although the Archaic is generally considered to follow the Paleo-Indian, there is increasing evidence in south and central Texas of a transitional phase following the end of the Paleo-Indian period and preceding the presently defined "Early Archaic." The information on this transition, tentatively labeled the "Pre-Archaic" (Sollberger and Hester 1972) comes from a series of sites with distinctive lithic traits: notched and triangular dart points, large, barbed points and stemmed points termed Gower (Hester 1975).

The Archaic Period (ca. 6000 B.C.-A.D. 1000) is represented in the vicinity of the study area by stemmed and triangular dart points, lithic tools identified as Clear Fork and Guadalupe, and large, thin bifaces. Believed to encompass a long span of hunting and gathering lifeways, the Archaic is presently divided into three major units: Eariy, Middle and Late. The highest frequencies of datable sites near the Tobins Oakwell Farm development are linked to Middle and/or Late Archaic occupations (Hester et al. 1974).

The third period, the Late Prehistoric/Neo-American (ca. A.D. 1200+) was marked by the introduction of new hunting techniques and cultural patterns due to the bow and arrow. Abruptly modified assemblages, new lithic forms, bone-tempered pottery and small arrow points of distinctive size made their appearance after A.D. 1200.

The Historic period is defined as the phase of post-European contact. During this time, south Texas was occupied by smali groups of semi-nomadic hunters and gatherers thought to have shared a common language termed "Coahuiltecan." This over-simplification and assumption of common traits has come under contemporary criticism and it has become evident that many cultural and linguistic differences existed amoung the groups. By the 18th and 19th centuries, these indigenous groups were destroyed by diseases, assimilated, or "missionized" into oblivion. Intrusive Plains Indians such as the Lipan Apache and the Comanche dominated during these times. 


\section{SITE DESCRIPTIONS}

Descriptions of various archaeological sites located and recorded during the survey follow the format listed below. The initial site designations are temporary identifications using a three-letter combination (TOF indicating Tobins 0akwell Farm) and a number which was assigned to the individual site. Site numbers were given in order of discovery and consecutively numbered sites do not necessarily imply cultural relationships. Each site has also been assigned permanent designations following the standard trinomial convention in which the first number, 41 , represents Texas; the two letters, $B X_{\text {, }}$ denote Bexar County; and the last number designates a specific site. Site descriptions also include the following standard information (cf. Nunley and Hester 1975):

Location: Indicates the site as viewed from topographic and environmental contexts. Sites are located in relation to known topographic features.

Elevation: Elevation above ms 1 as recorded on U.S.G.S. topographic maps, 1:24,000, unless otherwise specified. Elevations are given in feet to correspond with project and U.S.G.S. maps.

Description: Specific brief statements concerning the archaeological evidence, its extent, depth and condition.

Type of site: Identifies the aboriginal activity: occupational (campsite), Tithic scatter (brief occupation or limited use of area), quarry, lithic workshop, etc.

Environmental characteristics: A brief description of the major geographic and environmental characteristics of individual sites. Descriptions may include information on the local topography, soils and vegetation.

Interpretation/Remarks: A preliminary statement concerning the extent, importance, and condition of the site; this section will include recommendations for future research.

For a definition of unfamiliar terms sometimes used in the following sections, especially those used in site and artifact descriptions, the reader is referred to Fox and Hester $(1976: 13,14)$ for an excellent summary of commonly used archaeological terms relevant to the study.

TOF-1 (41 BX 473)

Location: Ca. $10 \mathrm{~m}$ east of Ira Lee Road and ca. $150 \mathrm{~m}$ south of Loop 410 West. Elevation: Maximum $710^{\prime}$, minimum $680^{\prime}$ above ms 1 .

Description: Located on an eroding terrace edge ca. $60 \mathrm{~m}$ west of the creek. Artifacts consist of a light scattering of tertiary flakes and an occasional core. Site is ca. $10 \times 10 \mathrm{~m}$ (Fig. 2).

Type of site: Lithic scatter. 
Environmental characteristics: Brown loam on upper terrace with al7uvial deposition on lower elevations. Dense brush with hackberry and small oak groves.

Interpretation/Remarks: No further work is recommended at this site.

TOF-2 $(41$ BX 474$)$

Location: Ca. $5 \mathrm{~m}$ east of Ira Lee Road and ca. $200 \mathrm{~m}$ south of Loop 410 West, Ca. $50 \mathrm{~m}$ downstream from TOF-1 (Fig. 2).

Elevation: Maximum 730', minimum $680^{\prime}$ above ms 1 .

Description: Site is ca. $10 \times 12 \mathrm{~m}$ and is located on an eroding terrace edge ca. $40 \mathrm{~m}$ west of the creek. Evidence consists of secondary and tertiary flakes with an occasional core.

Type of site: Lithic scatter.

Environmental characteristics: Dense brush, no grasses; trees include hackberry, oak and live oak. Site is located on slopes and upland adjacent to drainage.

Interpretation/Remarks: No further work is recommended.

TOF-3 $(41$ BX 475$)$

Location: Ca. $10 \mathrm{~m}$ east of Ira Lee Road and ca. $300 \mathrm{~m}$ south of Loop 410 West, ca. $60 \mathrm{~m}$ downstream from TOF-2 (Fig. 2).

Elevation: Maximum $720^{\prime}$, minimum $680^{\prime}$ above ms 1 .

Description: Located on an eroding terrace edge ca. $10 \mathrm{~m}$ west of Salado Creek. Site is ca. $10 \times 10 \mathrm{~m}$. Evidence consists of secondary and tertiary flakes.

Type of site: Lithic scatter.

Environmental characteristics: Vegetation includes dense brush with climax vegetation of hackberry, oak and persimmon. Site is located on slopes and upland area adjacent to drainage.

Interpretation/Remarks: No further work is recommended.

TOF-4 $(41$ BX 476$)$

Location: Adjacent to Ira Lee Road, ca. $500 \mathrm{~m}$ south of the intersection with Loop 410 West (Fig. 2).

Elevation: Maximum $720^{\prime}$, minimum $695^{\prime}$ above ms 1 . 
Description: Located on an eroding terrace and slope ca. $50 \mathrm{~m}$ west of Salado Creek. Artifact evidence includes flakes, cores and patinated, trimmed flakes.

Type of site: Lithic scatter/occupation, possibility of a deflated midden.

Environmental characteristics: Brown loamy soil on uplands, caliche and gravel on eroding slopes. Moderate brush cover with the climax vegetation being oaks.

Interpretation/Remarks: More intensive survey and limited testing to determine site potential.

TOF-5 (41 BX 477)

Location: Ca. $250 \mathrm{~m}$ east of Ira Lee Road and $\mathrm{ca} .260 \mathrm{~m}$ south of the intersection with Loop 410 West (Fig. 2).

Elevation: Maximum 696', minimum 690' above ms 1.

Description: Located on a terrace slope near the Granberg II site (41 BX 271). Evidence consists of flakes, cores and biface fragments. Most materials are exposed along present trails through the vicinity.

Type of site: Possible distinct areas of $1 i$ thic scatters.

Environmental characteristics: Brown soil and eroding gravels predominate. Oak groves and high grasses characterize the site area.

Interpretation/Remarks: No further work recommended but the developers are urged to contact the Center if further materials are uncovered during the project.

TOF-6 (41 BX 478)

Location: Ca. $150 \mathrm{~m}$ west of Salado Creek and $1.15 \mathrm{~km}$ south of Loop 410 West.

Elevation: Maximum $685 !$, minimum $675^{\prime}$ above ms 1 .

Description: Located on a terrace and flanked by lower-lying ground to the east and west. Flakes and occasional cores characterize the site, which is ca. $20 \mathrm{~m}$ east-west $\times 50 \mathrm{~m}$ north-south (Fig. 3 ).

Type of site: Thin lithic scatter.

Environmental characteristics: Brown soils with some erosion along the terrace. The site is located within a localized upland remnant which slopes east toward the drainage and west toward a (dry) former channel of the creek.

Interpretation/Remarks: No further work is recommended. 


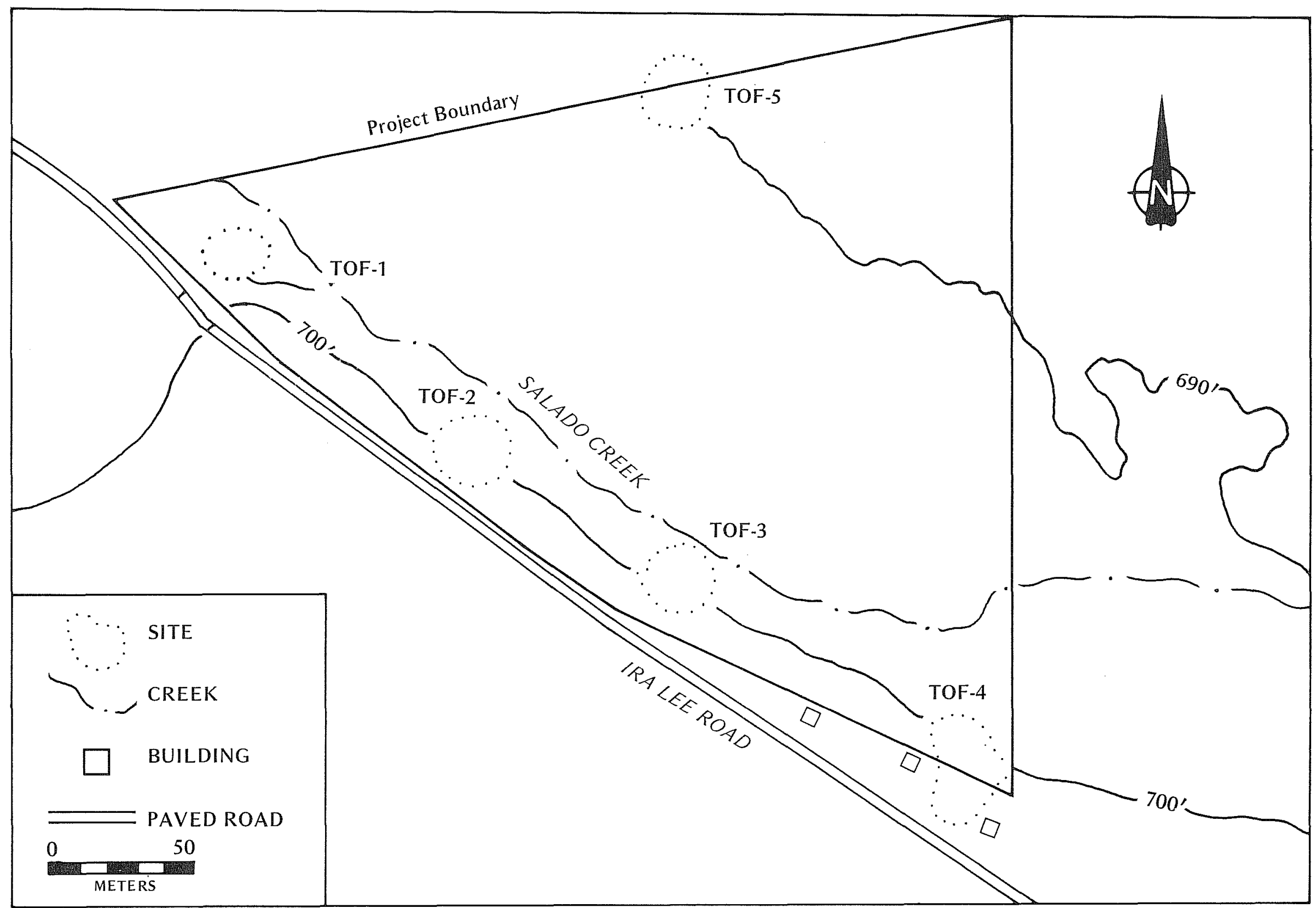

$\bullet$

Figure 2. Tobins Oakwell Farm: Site Locations. Sites TOF-1 (41 BX 473), TOF-2 (41 BX 474), TOF-3 (41 BX 475), TOF-4 (4i BX 476) and TOF-5 (41 BX 477). 
TOF-7 $(41$ BX 479)

Location: Ca. $200 \mathrm{~m}$ west of Salado Creek and $1050 \mathrm{~m}$ south of Loop 410 (Fig. 3). Elevation: Maximum 684', minimum $679.5^{\prime}$ above ms 1.

Description: Site is located primarily in the former (dry) channel of the creek and is ca. $70 \mathrm{~m}$ north-south $\times 20 \mathrm{~m}$ east-west. Lithic debris in the form of scrapers, cores and assorted flakes is scattered throughout.

Type of site: Lithic workshop/quarry.

Environmental characteristics: Site is located in the channel of a dry creek. Dense brush occurs along the fringes and short grasses predominate the site.

Interpretation/Remarks: The unusual preservation of the lithic patterning throughout the site suggests several possibilities which can only be resolved by further investigation (see Summary and Recommendations for further comments).

TOF-8 $(41 \quad B \times 480)$

Location: Ca. $200 \mathrm{~m}$ east of Ira Lee Road and ca. $570 \mathrm{~m}$ north of Austin Highway. Elevation: Maximum 684.9', minimum $680^{\prime}$ above ms 1 .

Description: The major part of the site is a plowed field. Flakes and a few cores comprise the lithic evidence. Site is ca. $70 \mathrm{~m}$ east-west and $45 \mathrm{~m}$ northsouth (Fig. 4).

Type of site: Lithic scatter.

Environmental characteristics: Medium-brown soil covers the site with oak trees on the fringes. Short grasses dominate the site. The site is located on a flat, possibly fossil, floodplain of Salado Creek.

Interpretation/Remarks: No further work is recommended.

TOF-9 $(41$ BX 481$)$

Location: Ca. $300 \mathrm{~m}$ east of Ira Lee Road and ca. $650 \mathrm{~m}$ north of Austin Highway. Elevation: Maximum 681.7', minimum 672' above ms 1 .

Description: Site is located on an upland remnant. Lithic materials include cores and several unifacial tools. Site area is ca. $120 \mathrm{~m}$ east-west $\times 80 \mathrm{~m}$ north-south (Fig. 4).

Type of site: Lithic workshop/possible occupation. 


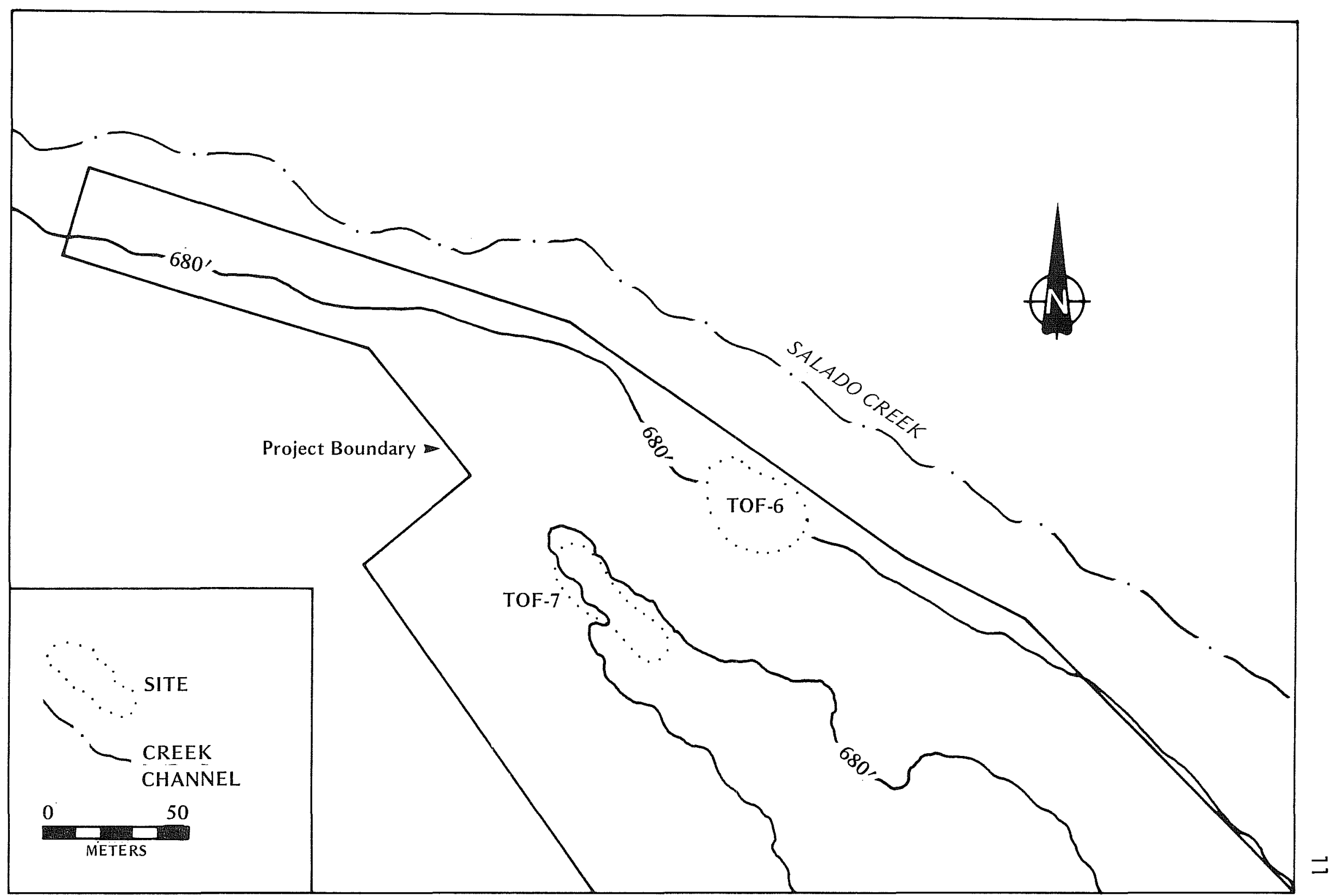

Figure 3. Tobins Oakwell Farm: Site Locations. Sites TOF-6 (41 BX 478) and TOF-7 (41 BX 479). 


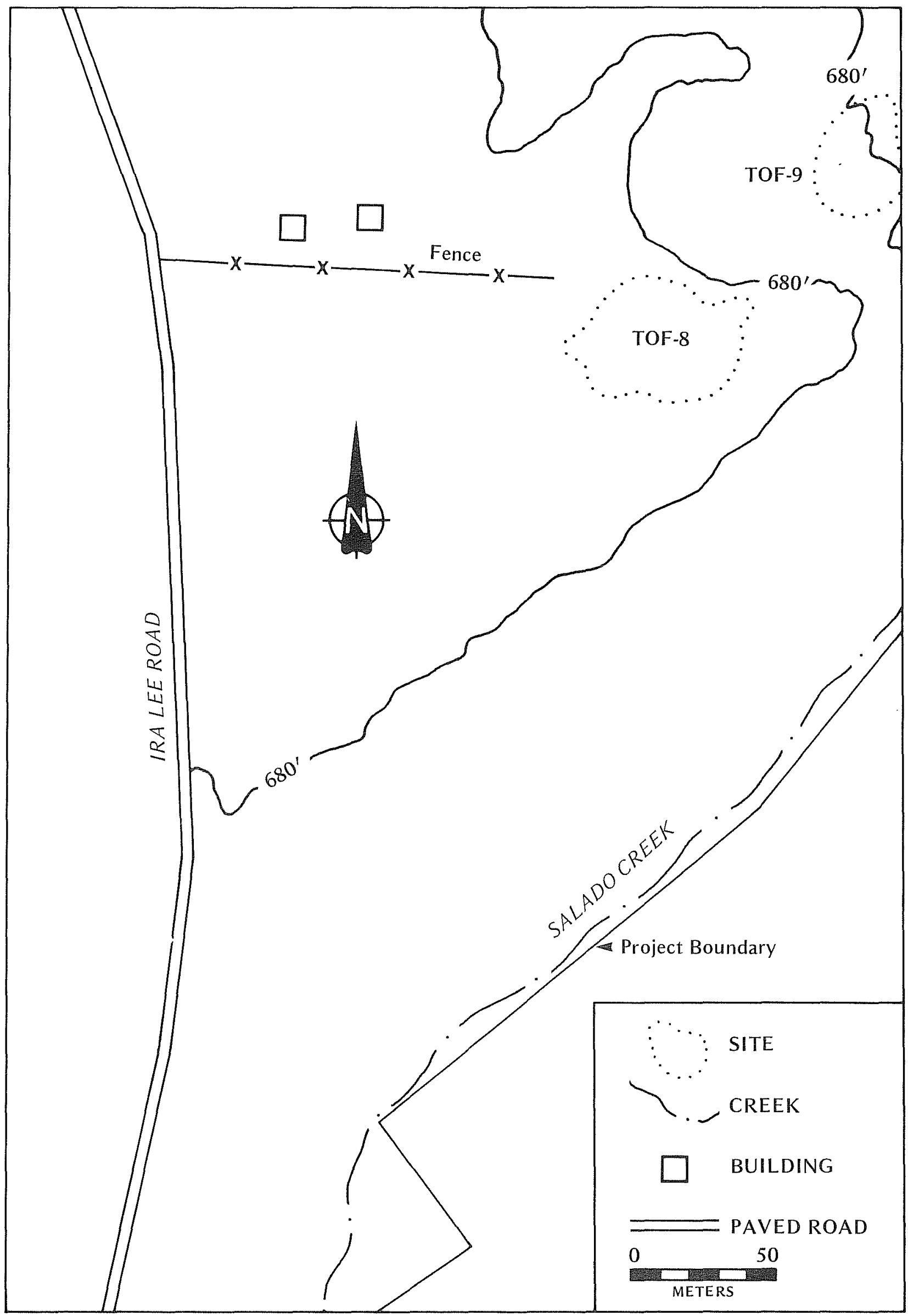

Figure 4. Tobins Oakwell Farm: Site Locations. Sites TOF-8 (41 BX 480) and TOF-9 (41 BX 481). 


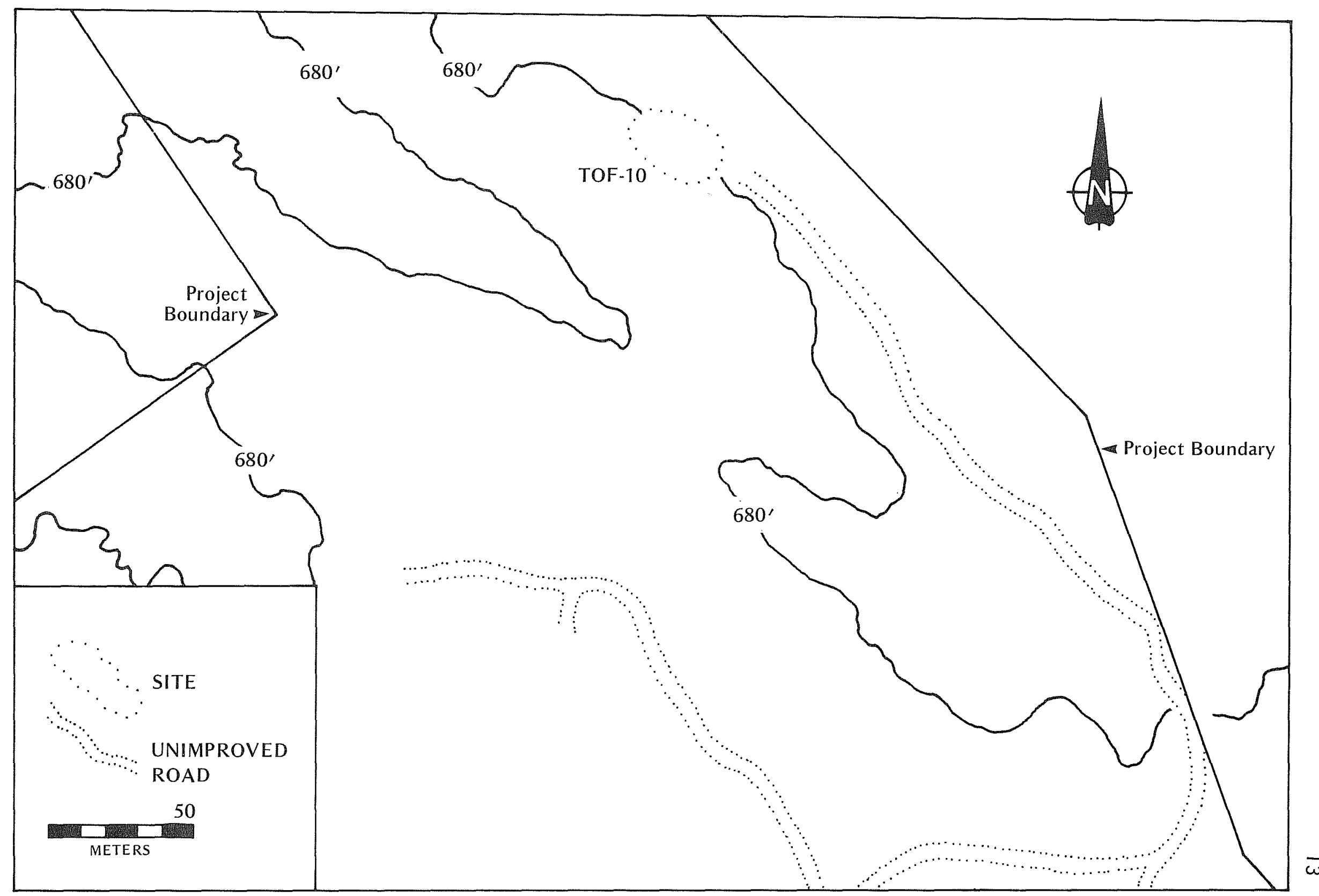

Figure 5. Tobins Oakwell Farm: Site Location. Site TOF-10 (41 BX 482). 
Environmental characteristics: Site is located on sma11 uplands area adjacent to a smalT tributary of Salado Creek. Dense brush and large trees cover most of the site.

Interpretation/Remarks: Additional testing is required to determine the extent and potential of this site.

TOF-10 (41 BX 482)

Location: Ca. $40 \mathrm{~m}$ west of the Salado Creek drainage and $\mathrm{ca} .1 .2 \mathrm{~km}$ north of Austin Highway (Fig. 5).

Elevation: Maximum $684^{\prime}$, minimum $675^{\prime}$ above ms 1 .

Description: Site is located within a city dumping/refuse area in a highly disturbed soil zone. Little remains of the original site and archaeological evidence is scattered throughout. Secondary and tertiary flakes were found eroding about $3 \mathrm{~m}$ below the surface in a large bulldozer cut.

Type of site: Lithic scatter.

Environmental characteristics: Gravel and trash fill; area is badly disturbed by modern alteration.

Interpretation/Remarks: No further work is recommended.

\section{THE ARTIFACTS}

Artifacts from the Tobins 0akwell Farm were collected from the surface on the basis of diagnostic potential and are considered representative of the types of materials occurring in the survey area. In all cases, archaeological evidence was 7 imited to Tithic materials. No diagnostic projectile points were found and the collected artifacts include cores, unifacial and end scrapers, large biface fragments, worked flakes, and assorted fragments of lithic debris. Detailed records are on file with the Center for Archaeological Research.

No detailed descriptions are presented; however, Figs. 6 and 7 illustrate many of the collected specimens and are indicative of the range of artifacts found during the survey.

\section{SUMMARY AND RECOMMENDATIONS}

A total of 10 prehistoric sites was located and recorded during the course of the survey. Sixty percent were situated on slopes or upland areas while the rest were in low-lying or formerly low-lying areas of the Salado Creek drainage. Al though no projectile points were collected, other lithic materials suggest that five sites reflect light to moderate multifunctional activities (1ithic workshop and occupations), and the other five were interpreted as lithic workshops. 

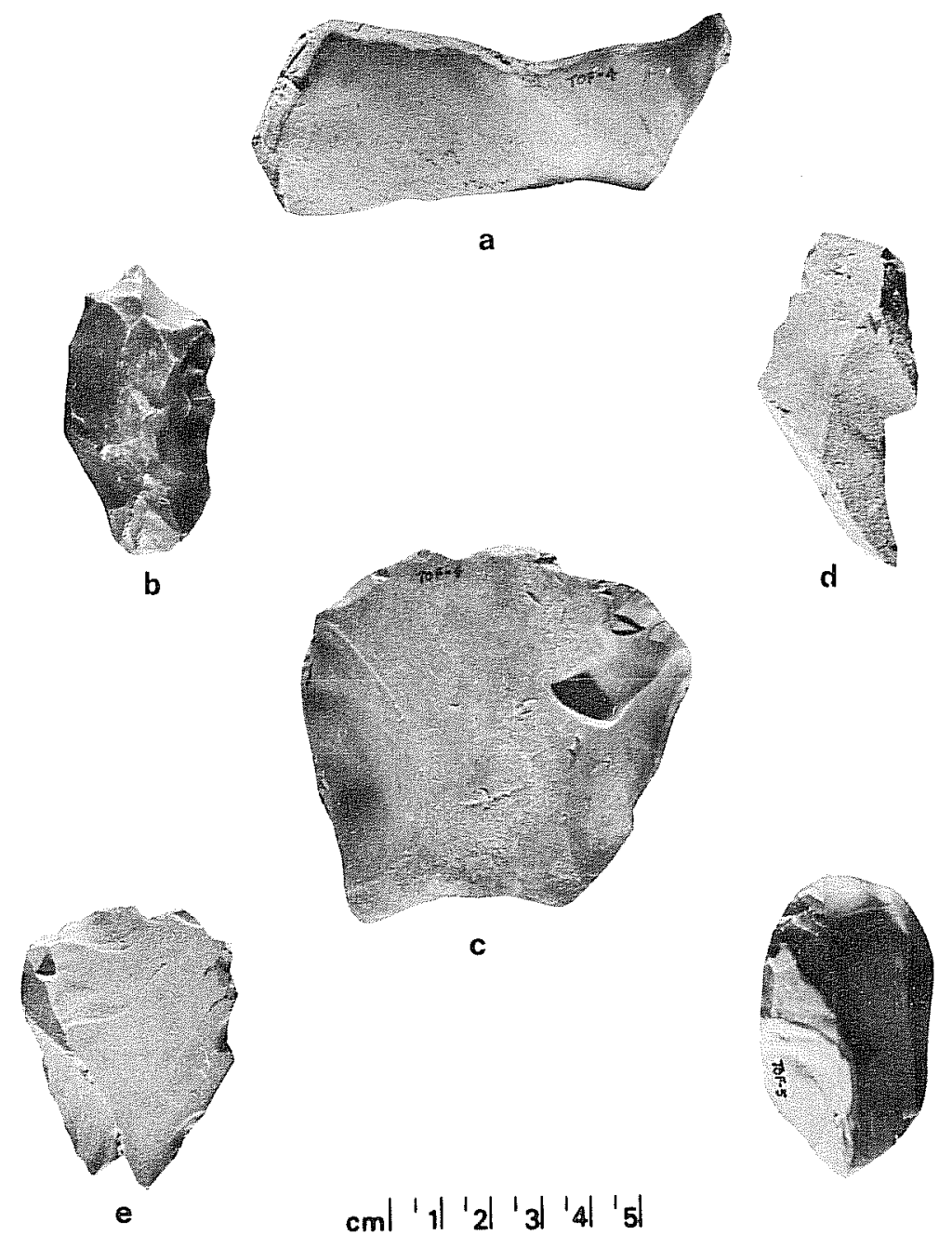

Figure 6. Lithic Artifacts. TOF-4 (41 BX 476): a, worked secondary flake; b, small biface; c, sma11 core. TOF-5 (41 BX 477): d, worked secondary flake; $f$, large flake. TOF-6 (41 BX 478): e, small biface. 


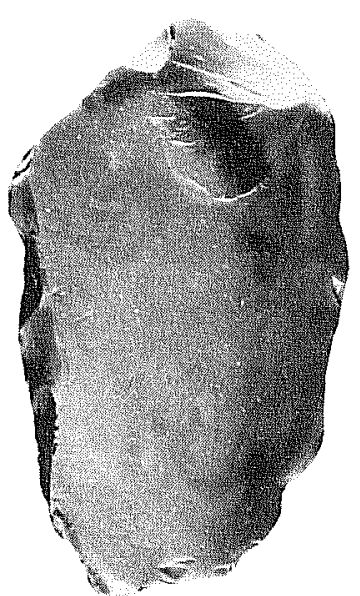

a

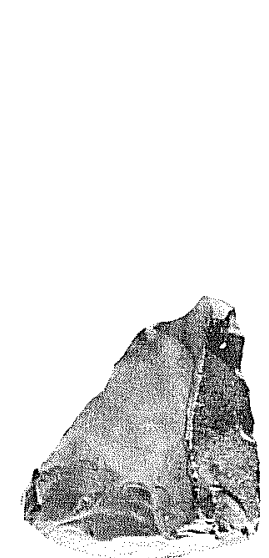

h

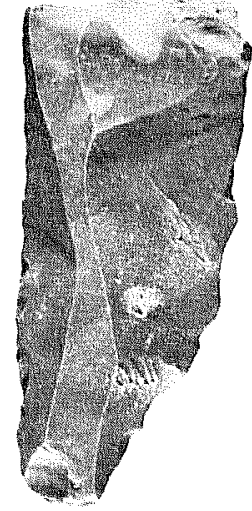

b

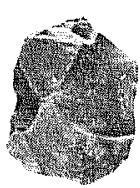

$f$

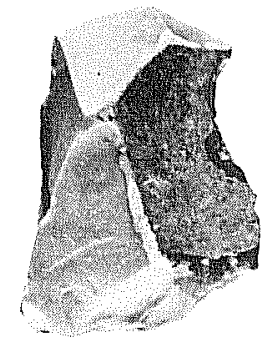

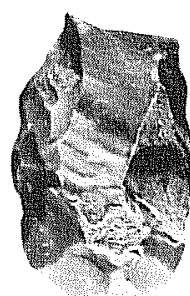

c

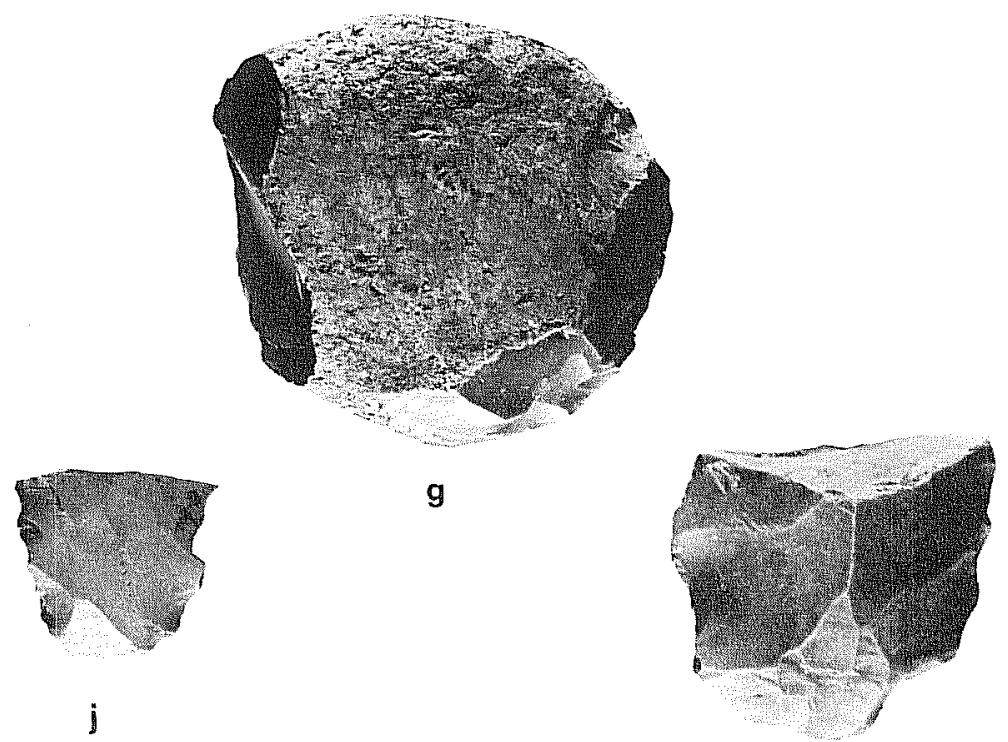

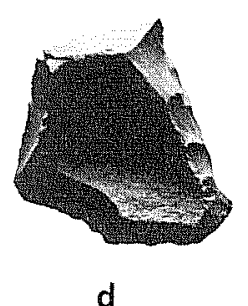

d

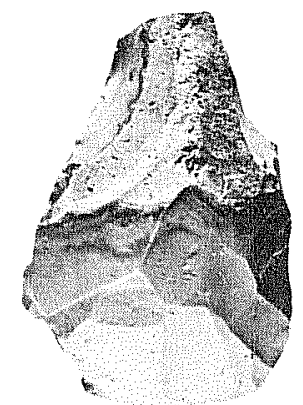

e

k

$\vec{\sigma}$

Figure 7. Lithic Artifacts. TOF-9 (41 BX 481): a, b and $h$, worked primary flakes. TOF-10 (41 BX 482 ): $f$, tertiary flakes; $i$, secondary flake. TOF-7 (41 BX 479): c, sma11 core; d, worked secondary flake; e, smal1 core fragment. TOF-8 (41 BX 480): $g$, core; $j$ and $k$, thick biface fragment. 
Because of the intensive modern damage to one site, TOF-10 (41 BX 482), it cannot be accurately placed into either a multifunctional or more limited category. Since only secondary and tertiary flakes were found, it has been tentatively categorized as a workshop site.

The 0akwell Farm project's strategic position in the aboriginal activity patterns of the past cannot be readily discerned from the information of the preliminary survey. While containing a moderate number of prehistoric sites along the waterway, the project area does not offer any conclusive evidence of major occupations. The limited extent of the sites as a whole and their lack of diagnostic projectile points seriously compromise even the most tenuous links with the archaeologically rich sites in the immediate vicinity.

The relatively large number of 1 ithic tools in the form of reworked secondary flakes suggests moderate occupation activity. A problem inherent in the study area and reflected by the evidence at TOF-10 (41 BX 482) may be that many more sites exist along the eastern margins of the project area but are deeply buried beneath several meters of alluvium. Another problem noted throughout the survey was unusually dense ground cover, and the developers are urged to contact the Center if further archaeological materials are uncovered.

The survey operations indicate the need for further intensive survey and 1 imited testing at the following three sites:

1) TOF-10 (41 BX 476): A multifunctional 1ithic workshop/occupation site that encompasses a slope and upland area ca. $90 \mathrm{~m}$ north-south $x 50 \mathrm{~m}$ east-west. The amount of artifacts suggests an intensive prehistoric activity area.

2) TOF-7 (41 BX 479): A workshop and possible quarrying site. Lithic debris in the form of scrapers, cores, primary, secondary and tertiary flakes is scattered for about $70 \mathrm{~m}$ along the bottom of a former dry creek channel. The unusual preservation of the lithic debris concentrations in specific areas indicates that specific activity areas may be identified by further investigations.

3) TOF-9 (41 BX 481): A multifunctional workshop/occupation site, which, because of dense ground cover, was not clearly defined. Lithic materials cover a wide area (ca. $120 \mathrm{~m}$ east-west $\times 80 \mathrm{~m}$ north-south), suggesting moderate to heavy occupation. Artifacts included cores and unifacial tools.

After laboratory analysis, one further site, TOF-5 (41 BX 477), is suggested as having a potential for additional research. A careful correlation of field notes and other sources implies TOF-5 may be the fringe area of the stratified and archaeologically important Granberg II site (41 BX 271). While the Gran,berg II site is not on project property, the margins may extend roughly 30 to $50 \mathrm{~m}$ into the development area. While no further survey or testing is suggested at this site, this report recommends that the developers contact the center if any further archaeological materials are uncovered here. 
REFERENCES CITED

Blair, W. F.

1950 The Biotic Provinces of Texas. Texas Journal of Science 2(1):93-116.

Carr, J. T., Jr.

1969 The Climate and Physiography of Texas. Texas Water Development Board, Report 53.

Chadderdon, M. F.

1975 Notes on the Menger Collection, Site 41 BX 272, Bexar County, Texas. La Tierra 2(1):15-18.

Fawcett, W. B., Jr.

1972 The Prehistory of Bexar County: A Study of Previous Work in South Central Texas. Bulletin, Lower Plains Archaeological Society 2 (for 1971).

1974 A Preliminary Analysis of Prehistoric Utilization of Upland Areas Adjacent to Leon Creek, South Central Texas. La Tierra $1(1): 27-31$

Fox, A. A. and T. R. Hester

1976 An Archaeological Survey of Coleto Creek, Victoria and Goliad Counties, Texas. Center for Archaeological Research, The university of Texas at San Antonio, Survey Report 18.

Gerstle, A., T. C. Kelly and C. Assad

1977 The Fort Sam Houston Project: An Archaeological and Historical Assessment. Center for Archaeological Research, The University of Texas at San Antonio, Archaeological Survey Report 40.

Hester, Thomas R.

1975 Archaeological and Historical Resources in the San AntonioGuadalupe River Basins: A Preliminary Statement. Center for Archaeological Research. The University of Texas at San Antonio, Regional Studies 1.

Hester, Thomas R., Feris A. Bass, Jr., Anne A. Fox, Thomas C. Kelly, Mary F. Chadderdon and E. S. Harris

1974 Archaeological Survey of Areas Proposed for Modification in the Salado Creek Watershed, Bexar County, Texas. Center for Archaeological Research. The University of Texas at San Antonio, Survey Report 3. 
Hester, Thomas R. and H. Kohnitz

1975 The Chronological Placement of Guadalupe Tools. La Tierra $2(2): 22-25$.

Hester, Thomas R., R. F. Heizer and J. A. Graham

1975 Field Methods in Archaeology, 6th Edition. Mayfield Publishing Company, Palo Alto, California.

Hester, Thomas R., F. A. Bass and T. C. Kelly

1975 Archaeological Survey of Portions of the Comal River Watershed, Comal County, Texas. Center for Archaeological Research. The University of Texas at San Antonio, Survey Report 6.

Hudson, W. R., Jr., W. M. Lynn and D. Scurlock

1974 Walker Ranch, An Archaeological Reconnaissance and Excavations in Northern Bexar County, Texas. Texas Historical Commission, Report 26.

McGraw, A., F. Valdez, Jr. and W. Cox

1977 An Archaeological Survey of Areas Proposed for Modification in the Encino Park Development, Northern Bexar County, Texas. Center for Archaeological Research. The University of Texas at San Antonio, Archaeological Survey Report 39.

Nunley, P. and T. R. Hester

1975 An Assessment of Archaeological Resources in Portions of Starr County, Texas. Center for Archaeological Research. The University of Texas at San Antonio, Archaeological Survey Report 7.

Schuetz, M. K.

1966 The Granberg Site: An Archaic Indian Habitation in Bexar County, Texas. Witte Museum Studies 1, San Antonio.

Scurlock, D. and W. R. Hudson

1973 An Archaeological Investigation of Walker Ranch. Texas Historical Commission, Austin.

Sollberger, J. B. and T. R. Hester

1972 The Strohacker Site: A Review of Pre-Archaic Manifestations in Texas. Plains Anthropologist $17(58): 326-344$.

Smith, H. P., Jr. and K. McDonald

1975 An Archaeological Survey of Friedrich Park, Bexar County, Texas. Center for Archaeological Research. The University of Texas at San Antonio, Archaeological Survey Report 12. 
Taylor, F. B., R. B. Hailey and D. L. Richmond

1966 Soil Survey of Bexar County, Texas. U.S. Department of Agriculture, Soil Conservation Service, Series 1962.

Woolford, S. W.

1935 Types of Archaeological Sites in Bexar County, Texas. Witte Museum Archaeological Bulletin 4, San Antonio. 